\title{
Editorial
}

Pathobiology

Pathobiology 2009;76:275-276

DOI: $10.1159 / 000245892$

\section{Translational Research in Cancer: Time to Reevaluate}

\section{M.A. Reymond}

Otto von Guericke University Magdeburg, Magdeburg, Germany

Translational research aims to better understand the role that genes play in disease, the effectiveness and safety of therapies, and many other biological factors that affect human well-being. The first DNA microarray allowing highly parallel genetic assays was commercialized in the late 1980s. In the meantime, translational research technologies have been used by the scientific and medical communities to investigate cancer. Twenty years later, over 10 '000 publications can be found with the key words 'cDNA array' and 'cancer'.

Cancer is a complex disease and, according to the stage of carcinogenesis, gives rise to different phenotypes and clinical stages of disease. For example, colorectal carcinogenesis begins with normal epithelium, proceeds with adenoma, carcinoma and ends with metastasis. Moreover, epithelial cancer arises in different tissues such as lung, prostate, colon and breast. Epithelial cancers are classified into different histological types such as adenocarcinoma and squamous cell cancer.

The aim of translational research is translating research results into clinical applications. It is very likely that translational research technologies have already delivered data allowing groundbreaking discoveries in cancer diagnosis, prognosis and therapy. However, many had expected more, or perhaps faster results. Paradoxically, the main problem in translational research might be the data generated. The terabytes of data produced have made it virtually impossible for the individual researcher to get an overview on his own research domain.

\section{KARGER}

Fax +4161306 1234

E-Mail karger@karger.ch

www.karger.com (c) 2009 S. Karger AG, Basel

1015-2008/09/0766-0275\$26.00/0

Accessible online at:

www.karger.com/pat
The problem is not completely new. Already in 1999 , Dove [1] expected that the focus of biomedical research (here: proteomics) would shift from data generation into data analysis and interpretation. Ten years later, the scientific community has not progressed much further and many feel 'lost in translation'.

Some reasons why translational research in cancer is more diverging than converging have been pointed out. For mining data, these data must be:

- representative: there must be enough observations (for example patients) for the disease processes to be investigated,

- reproducible: similar data should be produced when analyses are repeated,

- traceable: when output results are produced, it is important to be able to define which input data have produced these results.

Unfortunately, these preconditions are not fulfilled in most published translational studies in epithelial cancer. Many studies have been performed with cell lines, fewer with human tissues and very few with enriched, wellcharacterized biopsies. Normal and pathological controls were extraordinarily rare. The number of patients was much too low to allow proper statistical analysis. Clinical information was hard to find in the publications. In most studies, follow-up data were not provided. Different technologies such as cDNA arrays, oligonucleotide arrays and serial analysis of gene expression were used, rendering comparison of results difficult. Furthermore, the reliabil- 
ity of these technologies has been questioned and common standards are missing [2]. The agreement between 2 technologies within the same lab was greater than that between 2 labs using the same technology [3]. These are all reasons for being not so optimistic.

Our group has compared translational research results by building 'data warehouses', a kind of simple metaanalysis, in colorectal cancer [4], breast cancer [5], lung cancer (see the article of Bührens et al. [6] in the present issue and of Amelung and coworkers in the next issue), prostate cancer, thyroid cancer and stomach cancer. Finally, we are in the process of integrating all results obtained in different tissues and histologies, with the aim of finding a common set of genes modified in all epithelial cancers and, perhaps, specific genes in various tissues and histologies. The results will be published in this journal.

\section{References}

1 Dove A: Proteomics: translating genomics into products? Nat Biotechnol 1999;17:233236.

2 Stoeckert CJ Jr, Causton HC, Ball CA: Microarray databases: standards and ontologies. Nat Genet 2002;32(suppl):469-473.

3 Wang H, He X, Band M, Wilson C, Liu L: A study of inter-lab and inter-platform agreement of DNA microarray data. BMC Genomics 2005;6:71.

4 Sagynaliev E, Steinert R, Nestler G, Lippert $\mathrm{H}$, Knoch M, Reymond MA: Web-based data warehouse on gene expression in human colorectal cancer. Proteomics 2005;5:30663078 .
5 Srour N, Reymond MA, Steinert R: Lost in translation? A systematic database of gene expression in breast cancer. Pathobiology 2008;75:112-118.

6 Bührens RI, Amelung JT, Reymond MA, Beshay M: Protein expression in human non small cell lung cancer: a systematic database. Pathobiology 2009;76:277-285. 